\title{
3. From Primitive Other to Papuan Self: Korowai Engagement with Ideologies of Unequal Human Worth in Encounters with Tourists, State Officials and Education
}

\author{
Rupert Stasch
}

On 12 December 2012, an Indonesian Air Force helicopter flew 230 miles north from the coastal city of Merauke to an unfinished dirt airstrip in the middle of the forested territory of Korowai people of Papua's southern lowlands. Korowai number only about 4,000 persons, but from among the many different peoples of Papua they have become uniquely prominent in the global mass media, where they are known for their 'treehouse' architecture and their supposed 'Stone Age' isolation from markets and the state. Their location, spread across the upper lowland watersheds of several rivers, and the lack of extractive resources there, have indeed meant that the Indonesian state has little direct administrative presence on their land. The helicopter expedition at the end of 2012 was unusual.

The aircraft carried the head of a government agency known as UP4B, or the Unit for the Acceleration of Development in the Provinces of Papua and West Papua. Indonesian president Susilo Bambang Yudhoyono created this agency in 2011, with the charge of rectifying the fact that most Papuans' lives had not actually been improved by the US\$3 billion in 'Special Autonomy' supplementary funding sent to Papua since 2001. At the helicopter's destination, meanwhile, airstrip construction had been underway for two years. The project was led by Western Dani men of a highland church called GIDI (Ipenburg 2008: 372; Pagawak 2007), who started missionising this part of the Korowai area in 2005. One of the highlanders had brokered the government visit from his office in town, and sent word by radio a day in advance about the helicopter's arrival. When the aircraft landed, the agency head and his entourage were met by 200 Korowai in a martial dance formation. Korowai men performed cycles of synchronised ululation and snapping of bowstrings, a dance genre normally enacted during ceremonial feasting or feuds. Most Korowai on the scene wore no clothing except traditional-dress genital coverings and festive adornments, though the government party did not know that the performers had only removed their shirts and shorts earlier that morning. 
The encounter soon transitioned into an exchange of objects and talk between spokesmen from each side, who earnestly stated how important the others were to themselves. The Javanese head of UP4B, a retired army Lieutenant General named Bambang Darmono, stated: 'I am so truly sad I am almost crying, that this nation has existed for almost seventy years and it turns out there are people who still live naked ... I thank God that I have had the opportunity to visit the Stone Korowai tribe who live as though in the Stone Age'. ${ }^{1}$ A senior Korowai man gave Darmono a series of emblematic artifacts, including a stone axe, a bow and arrow, house thatch, a wild yam, a palm leaf base, an animal tooth necklace, a bamboo tobacco pipe, a fire-saw, a bird-of-paradise skin headdress and a string bag. Via a younger man who translated into Indonesian, the elder explained the gifts' significance, namely that Darmono would 'join in experiencing our people's hardships' and be moved to give Korowai better substitutes. Handing over the stone axe, the man said, 'I now present this to Mr Boss [Bapak Kepala] so it can be replaced with cutting tools that are easier to use for felling trees and splitting logs.' Giving the palm leaf base, the man explained, 'This palm leaf base is used for eating sago. We present it to Sir, so Sir can replace it with plates.' He characterised the bow and arrow as signs of endemic violence and cannibalism, and their handover as an act of self-pacification:

This is for hunting, for shooting pigs and shooting cassowaries, and for killing people. If someone elopes with someone's daughter, this is for fighting. And regularly when people want to eat someone, need to kill a witch, I routinely use this to kill. And feuding, here in the Korowai area, [we] use this all the time. What this arrow here is for is, I go on killing people and eating them. Up until now, when I give it up. I want to give it to Sir. ${ }^{2}$

1 Sungguh saya sedih dan mau menangis, hampir 70 tahun negara ini ada ternyata masih ada yang hidup telanjang ...Saya bersyukur kepada Tuhan telah mendapat kesempatan bisa datang di kelompok Suku Korowai Batu yang hidup layaknya zaman batu (www.up4b.go.id/index.php/prioritas-p4b/10-sosial-budaya/item/108suku-korowai-batu-bangun-lapangan-terbang-dengan-kapak-batu). Across this chapter, I distinguish Indonesian speech in underlining from Korowai speech in italics. All URLs about the Darmono visit cited in this and later notes were accessed 28 February 2013.

2 The first three of the senior Korowai man's statements are from UP4B publicity reports, where it is the younger Korowai man's translation into Indonesian that is written down (altered by dialect features of the standard Indonesian spoken by agency staff). The phrase 'join in experiencing our people's hardships' (agar bapak bisa ikut merasakan bagaimana susahnya rakyat kami) is from www.up4b.go.id/index.php/prioritas-p4b/10-sosial-budaya/item/116pertemuan-dua-kepala-yang-sarat-dengan-pesan-perubahan. The statement about the stone axe was Sekarang saya serahkan ke Bapak Kepala agar diganti dengan alat tebang lebih mudah untuk digunakan tebang pohon dan belah kayu (www.up4b.go.id/index.php/prioritas-p4b/10-sosial-budaya/item/100-kunjungan-kepala-up4b-dan-sebuahketelanjangan-kehidupan-suku-korowai). The statement about the leaf base was Pelepah ini, biasa digunakan untuk alas makan sagu, kami serahkan kepada bapak, agar bapak mengganti ini dengan piring (www.up4b.go.id/index. php/prioritas-p4b/10-sosial-budaya/item/116-pertemuan-dua-kepala-yang-sarat-dengan-pesan-perubahan). The block quotation comes from a recording of the translator's speech in a news segment about Darmono's visit available at www.youtube.com/watch?v=qluNZiiKEJ4, originally broadcast on the Papuan regional station of state-owned TVRI. The translator's words, at 5:30, were: Ini busur. Panah. Ini, pakai ini berburu, panah babi, panah kasuari, dan pakai ini bunuh orang. Bawa lari orang punya anak dan merontak, pakai ini bunuh orang. Ya, biasa orang suka makan orang, suangi, bunuh, biasa pakai ini saya bunuh. Dan berperang, di daerah Korowai ini, pakai ini 


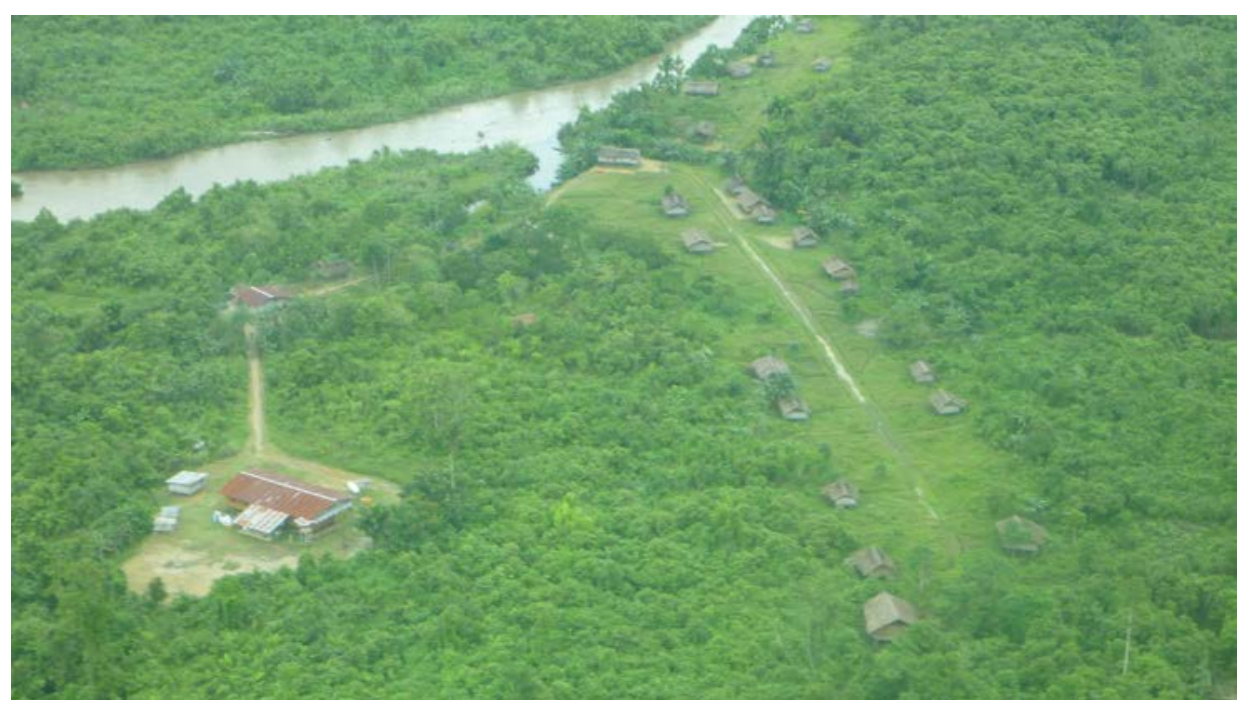

Figure 3.1. Danuwage village, July 2011. The airstrip is out of frame to the right. Aerial photos in UP4B's press release cropped out the large missionary residence at left.

Source: R. Stasch.

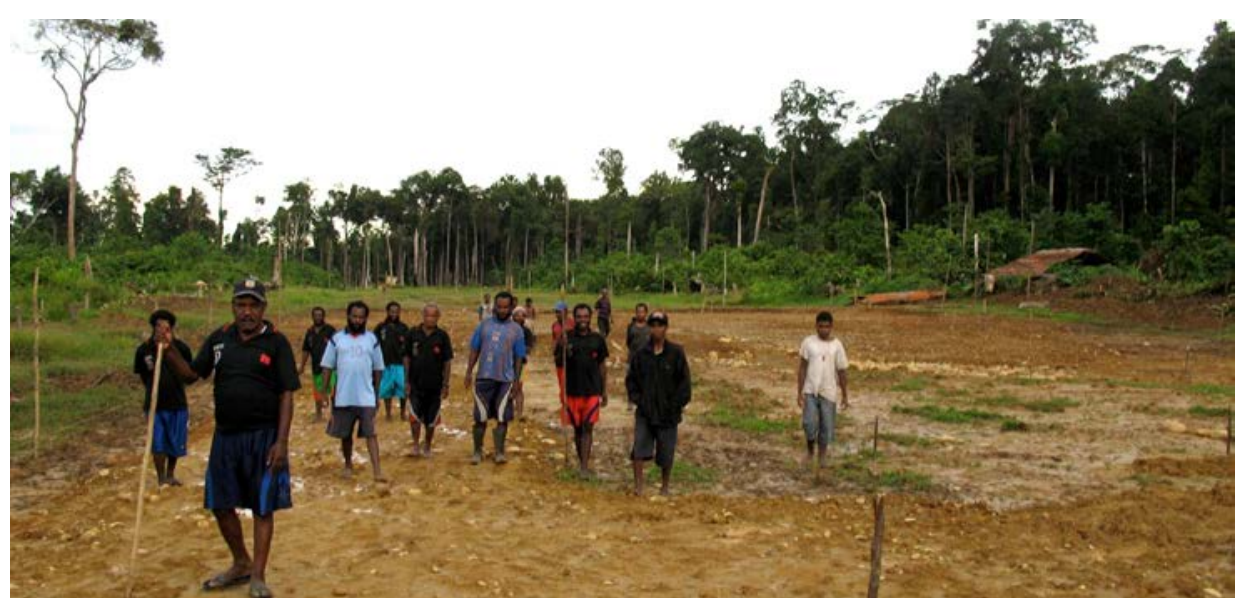

Figure 3.2. Ten Western Dani evangelists at the Danuwage airstrip, July 2011, with six Korowai in the distant background and at right.

Source: R. Stasch.

terus. Yang pakai panah ini, saya bunuh orang makan, terus. Sampai sekarang, saya lepas, mau kasih Bapak. His discourse reflects interference from Korowai grammar and pragmatics. On Korowai bilingualism in Indonesian, see Stasch (2007). 
Accepting the gifts, Darmono elaborated on the same transactional logic: 'My brothers and sisters whom I deeply love, all this that the Tribal Chief has given me is a symbol that the Tribal Chief has given to me the responsibility to ensure that this Stone Korowai community experiences and obtains development in future days. ${ }^{3}$ He listed infrastructure projects Korowai would receive, such as asphalting of the airstrip and construction of a school and clinic. Then his group flew away, without having walked the quarter-mile to Danuwage village, where in addition to houses of Korowai and Dani residents they would have seen the dwelling of an American missionary family who had lived there part-time since 2008, and who had coincidentally flown out by floatplane the previous day to evacuate an acutely ill Korowai woman (Figures 3.1 and 3.2). In the following weeks, UP4B staff publicised details of the visit via television and newspaper. Twenty months later, in August 2014, a government helicopter flew heavy equipment to the airstrip and a work crew began the asphalting job, as one of UP4B's showcase development projects.

What is most striking about the December 2012 encounter is its high degree of impromptu coordination between people who understood little about the wider background to each other's involvement. Central to this harmonisation was the category 'primitive', functioning within an overall logic of theatricalised exchange of 'primitivity' for 'development'. The category 'primitive' was signified not only through linguistic terms like 'Stone Age' (Zaman Batu) but also through more-than-linguistic signifiers such as material artifacts and bodily violence.

My topic in this chapter is how Korowai take up the category of the primitive as a self-understanding, acting toward and through this category in their relations with outsiders newly central to their world. Power imbalances between Korowai and outsiders mean that it would be valuable to analyse the category of the primitive as it functions for those who project it onto others in the first place (something partly addressed by Stasch $2011 \mathrm{~b}$ and 2014a). We have already seen that Darmono understands civilising of primitives to be a national imperative and a measure of Indonesia's true existence. ${ }^{4} \mathrm{He}$ invests great significance in

3 Saudara-saudaraku yang sangat saya cintai, apa yang diberikan Kepala Suku kepada saya, ini adalah lambang bahwa Kepala Suku memberikan tanggung jawab kepada saya untuk membuat masyarakat Korowai Batu ini merasakan dan mendapatkan pembangunan di hari-hari yang akan datang (at 8:10 in the video cited in note 2).

4 The theme of primitivity as a foundational site of the nation is further exemplified in Darmono's statement that 'I repeat, the nation has to be present here to lift up the lives of Stone Korowai to become a good community' (Sekali lagi negara, harus hadir di tempat ini untuk mengangkat kehidupan Korowai Batu menjadi masyarakat yang baik, www.up4b.go.id/index.php/prioritas-p4b/10-sosial-budaya/item/100-kunjungan-kepala-up4bdan-sebuah-ketelanjangan-kehidupan-suku-korowai). See also a PR officer's formulation that 'Among the Stone Korowai community we may encounter the original people of Papua in the true sense. Unblemished and without artifice. Truly authentic. In the aforementioned image of authenticity we encounter a different face of Indonesia' (Di komunitas Korowai Batu kita bisa menjumpai makna orang asli Papua. Tanpa noda, tanpa rekayasa. Sunguh asli. Dalam pancaran keasliannya tersebut kita menjumpai wajah Indonesia yang 
nudity, stone tool technology and 'tribal chiefs' (kepala suku), stereotypes deserving analysis. Also deserving analysis is how the figure of the primitive gives officials a role of paternalistic benefactor, obscuring harm done to Papuan people by actual state policies and practices. Yet in my fieldwork, I have been struck by the importance of the primitive as a self-understanding taken up by those to whom it is applied. While there is much scholarship on primitivist thought as projected onto others by those who see themselves as 'civilised', relatively little ethnographic attention has been given to reception of primitivist frameworks among people whom the frameworks are about (but see Gow 1993; Albert and Ramos 2000; Knauft 2002, 2007; Causey 2003; Pandian 2009). What the story of Darmono's visit to Korowai makes clear is that primitivist ideology is an important path of actual relating between stereotypers and the people stereotyped, thanks to Korowai perceiving and adopting outsiders' stereotypy of them, and actively performing in its terms.

Yet the idea of the primitive may differ between those who project it onto others, and those who hold it as a self-understanding. As part of my analysis, I also trace distinctive sensibilities structuring emergent Korowai concepts of the primitive. This is one level on which the comparative relevance of my discussion extends beyond the issue of primitivist ideology alone (important enough as it is), to take in more general questions of interethnic hierarchy and state formation. Ideas of primitivity are centred on claims about human otherness and unequal human worth. What has most heavily organised Korowai people's adoption of ideas of the primitive is their own sensibilities about social inequality, and about transacting with others across disparities of history and value.

The fluidity with which Korowai and state actors today relate is theoretically surprising, because Korowai in their own social relations uphold a radically egalitarian political ethos that could be described as 'anti-state' or 'anarchist' (following Clastres 1977; Scott 2009). For example, they previously had no named roles of political leadership, and they are very quick to rebuke anyone among themselves who tells others what to do, has more possessions than others, or claims to be better than others. Like other egalitarians, Korowai 'vote with their feet'. Their past extreme residential dispersion was motivated by the idea that dwelling apart allows people to live by their own wills (xul-melun, lit. 'thoughts'), whereas aggregating in one place would lead to conflicts over adultery, theft or other acts of one person unduly imposing on another (Stasch 2008, 2009, 2013).

beda, www.jurnas.com/halaman/12/2012-12-26/230221). Numerous publicity documents paint Darmono and the Korowai 'tribal chief' as analogous figures within their respective communities, and emphasise Korowai people's instant embrace of Darmono as a patriarchal authority. This suggests that the fantasy of an archaic hierarchical polity ruled by a 'tribal chief' embodying exceptional masculine virtue is a projection of modern bureaucratic authority's own wishful self-understanding. 
This chapter thus addresses a paradoxical question of how deep commitment to an anti-state political ethos can lead people toward the state rather than away from it. In the Korowai case, a first part of the answer lies in specific structural features of the state they are engaged with. Under Suharto, the Indonesian state was pervasively clientelistic (Aspinall 2013). But recent transformations have meant that in Papua specifically, the conditions for clientelism have greatly intensified. In all of Papua's immigrant-dominated towns, there are still hardly any Papuan-owned shops, service establishments, construction or transport companies, or other commercial enterprises involving fixed assets. Immigrants also dominate economically across the network of smaller administrative and commercial centres stretching out to the rural, gardening-based hinterland where Papuans are an overwhelming demographic majority. Alongside continued marginalisation from private enterprise, though, Papuans' situation with respect to state resources has shifted. The Special Autonomy law of 2001 required that high-tier civil offices be filled by Papuans, and that tax revenues from Freeport's Grasberg mine and BP's Tangguh gas project be primarily returned to regional coffers rather than absorbed in Jakarta. Meanwhile, Papua has also seen an extraordinary proliferation of new civil territorial units, at nested levels of 'province', 'regency', 'subdistrict' and 'village'. For example, the former total of nine regencies has now been remade into 40, with a further 30 soon to be instituted. This trend has followed an Indonesia-wide decentralisation policy, but subdivision in Papua has specifically functioned to counteract separatism and the power shifts entailed in Special Autonomy. It does so by dividing Papuan blocs from each other and by increasing civil servant jobs. In Papua these jobs already accounted for 30 per cent of nongardening employment, but in the first years of the subdivision process they tripled in number, from 37,000 to 114,419 (Booth 2011: 44; Institute for Policy Analysis of Conflict 2013: 5). Even more prominent has been the proliferation and localisation of high offices such as 'Regent' (Bupati) and 'subdistrict head' (Camat or Distrik). The new offices are lucratively funded, but have little established bureaucratic infrastructure beneath them and receive no effective capacity-building guidance. Thus decentralisation and increased financial resources have led not to improved delivery of state services, but to intensified corruption and clientelism, such as in the form of locally ascended civil leaders giving cash and consumables to outlying rural constituents in direct exchange for electoral support. As McWilliam (2011: 163) puts it,

For the majority of the population in these areas [on Papua's administrative periphery], engagement with formal government is severely constrained by its practical invisibility and inaction for much of the time. Occasionally, there are flurries of performative symbolism when officialdom is on show or election campaigns are in the air, but the presence of everyday government in action is patchy and inconsistent 
at best. Formal government on the margins, therefore, appears to be as much about the projection and regulatory intent of state power as it is about its practical implementation and tangible benefits.

Or as Anderson (2013) observes, 'district proliferation and the creation of new government offices often have nothing to do with the provision of services', with 'many local governments ... essentially functioning as nothing but distribution systems for cash, favours, and no-show jobs' (see also Timmer 2007; Widjojo 2014: 513).

Whatever the motives of central state actors, the goal of having new administrative units is now endorsed by most Papuan politicians and by local rural populations. The puzzle of Korowai people's active embrace of state power is in this way partly explained by top-down transformations in the nature of the state they are meeting. The new clientelistic and locally accessible state is a transactional other whom Korowai can more recognisably find their way to, through their own logics of exchange-based kinship.

But the preceding sketch of the structural context to what is today happening in the Korowai lands is only a preliminary to my main topic, the Korowai side of the 'working misunderstanding' that unfolds in scenes of encounter like what took place at the Danuwage airstrip. There are three ethnographic areas I examine in the rest of this chapter to give evidence that Korowai uptake of ideas of the primitive are driven and shaped by their own egalitarian political order. These areas are performance of primitivity for international tourists, performances for government heads, and migration to town for education.

\section{Performing the primitive toward tourists}

There is no such thing as 'primitive' people, except as created by other people's primitivism. Primitivism is any cultural framework that typifies a set of others as incarnating an archaic condition of humanity radically different from the condition of the stereotypers themselves. Global metropolitan publics today widely hold a model of a Manichaean contrast of 'primitive' and 'civilised' poles of humanity. This model is indebted to 19th-century anthropological theories of social evolution for its sense that the 'civilised' pole is history's telos. Additionally, this globally dominant primitivist model has strong if submerged overlaps with histories of racism and racial theory, as well as connections to the crypto-evolutionism of 'development'. Although ideological structures of 'primitivism' are my main focus across this chapter, one effect of looking at stereotyped people's own uptake of such ideologies is that the inter-implication of primitivist, evolutionary, racial and developmentalist models are made more explicit than usual. 


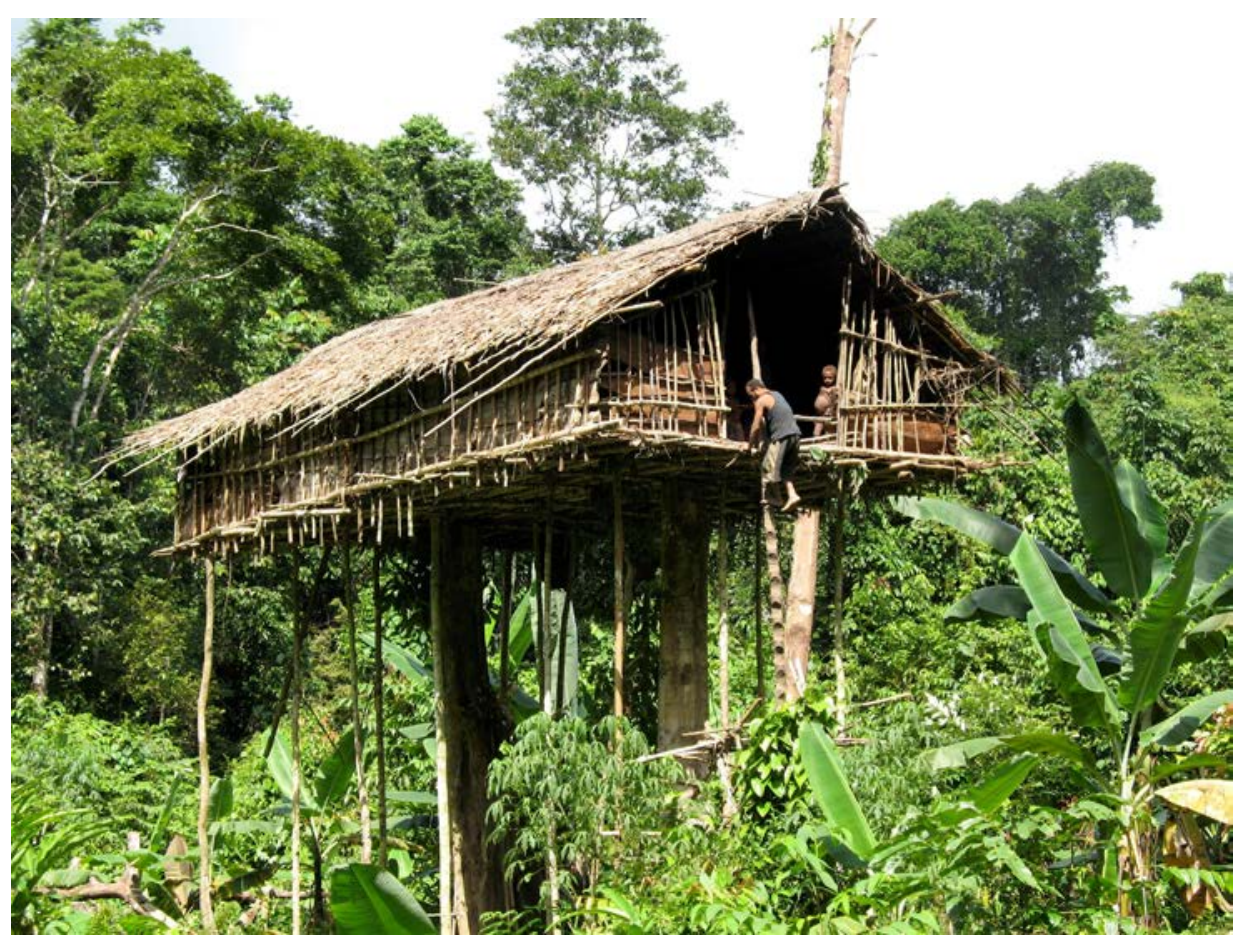

Figure 3.3. House of Melanux Waüop and her relatives, 2007.

Source: R. Stasch.

Korowai over the last 25 years have been the focus of a boom in primitivist tourism. They have been visited by thousands of travellers, coming from virtually all European states and most European settler colonies, as well as many East and Southeast Asian countries. Engagement with tourists has, for many Korowai, been more direct than engagement with state actors. It has been through tourism that ideas of the primitive have initially grown to importance in their social world.

Because the primitive is defined as a quality of authenticity and purity relative to something else that is corrupt, it is in the category's own logic to elicit a fractal subdivision of that to which it is applied. Metonymic parts are constantly hived off as true paragons of the primitive type. This is what has led to the boom in tourism to the Korowai area specifically. At least since the Cook voyages, Pacific peoples have had special standing as civilised Europe's radical others. Across the 1800s, the somewhat open intellectual foment provoked by Pacific cultural diversity hardened into fixed taxonomies of inferiority and superiority, and a new racialising distinction between Melanesia and Polynesia helped stabilise southwest Pacific peoples' status as the truly archaic pole of humankind (Smith 
1985, 1992; Douglas 1999, 2011; Douglas and Ballard 2008). An idea of New Guineans as the ultimate primitives deepened across the 20th century. Within travel discourse of the last several decades, there has been a tendency for the Indonesian-controlled western half of the island to be portrayed as the ultimate paragon of primitivity even relative to the island's eastern half, independent Papua New Guinea. And within Papua, treehouse-building Korowai have now become famous as the ultimate of the ultimate, possibly the most iconic figures of the primitive globally today (Figure 3). Tourists' meetings with Korowai have an aura of deep meaningfulness, because they experience Korowai as embodying the cosmological type of 'primitive humanity' on a world historical scale.

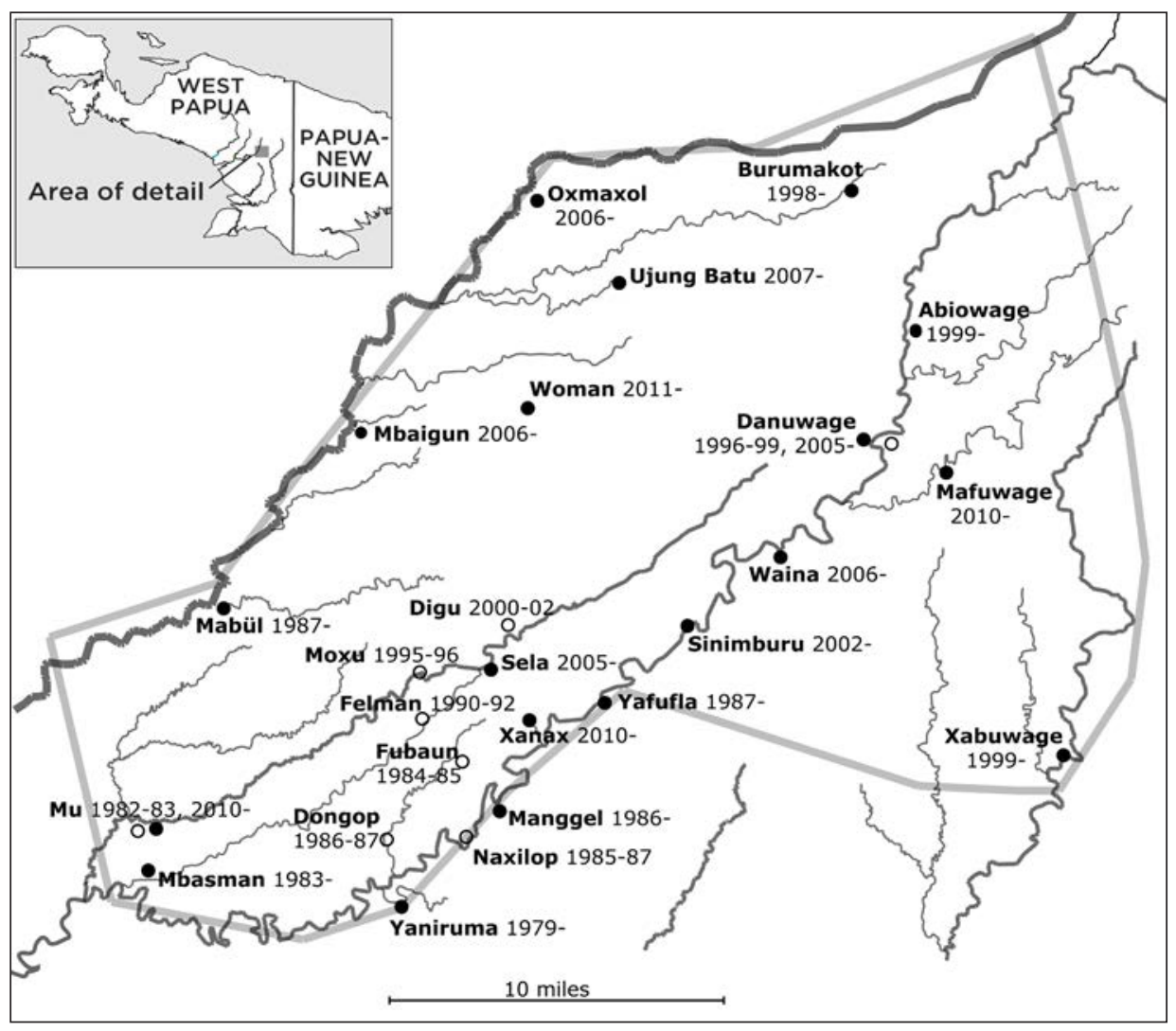

Figure 3.4. Korowai lands in West Papua, showing villages created since the founding of Yaniruma. Extant villages shown by solid dots, abandoned ones by circles.

Source: R. Stasch. 
Tour guides started bringing groups by boat to the southwestern edge of the Korowai area in the mid-1980s. Until 1978, when Dutch missionaries established the post of Yaniruma, Korowai had had no regular interaction with long-distance strangers. It was around 1990, at the beginning of a 10-year hiatus in missionary presence, that international tour groups began steadily travelling to the Korowai area, including by Cessna flights to the Yaniruma airstrip. Also in the 1990s, Korowai began to be featured in international mass media representations, such as the Outside Magazine story 'No Cannibal Jokes, Please: Upriver into the Swamps of Irian Jaya, and Back in Time' (Cahill 1992) and the Arts \& Entertainment Channel film 'Treehouse People: Cannibal Justice' (also distributed as 'Lords of the Garden', Hallet 1994). The most consequential media event was National Geographic's photo essay 'Irian Jaya's People of the Trees' (Steinmetz 1996), which shaped the expectations of many later visitors. Passages about how to visit Korowai and their Kombai neighbours began appearing in editions of Indonesia Handbook and New Guinea: Journey into the Stone Age, and later in the Indonesia guidebooks of Rough Guide and Lonely Planet (e.g. Dalton 1991: 1016-17; Müller 1990: 46; Backshall et al. 1999: 926; Berkmoes et al. 2010: 816). Professional guides recall that during tourism's peak around 1997, they would routinely cross paths with each other at the Yaniruma airstrip, bringing their groups in and out of the region. The 1990s also saw continuation of a process of village formation earlier initiated by the missionaries, in a downstream to upstream direction (Figure 4). The earlier pattern of dispersed residence on patriclan-owned forest territories gave way to a new practice of alternation between lone forest houses and the new centralised settlements (Stasch 2013).

Wider geopolitical events meant that few tourists visited from 1998 to 2002, and the flow of visitors has been erratic even since this temporary crash, limited above all by the high cost of airplane or boat charters to the area. Trips by media professionals, though, have increased in quantity, with a total of about 50 professional films now having been made about Korowai or Kombai. Film production particularly intensified with the global rise in popularity of reality TV shows in which home-country presenters 'go native' in a primitivism-marked destination. Two productions in this genre that were widely seen in Englishlanguage television markets, for example, were a 2005 Kombai episode of the wider series Tribe (also titled Going Tribal), and the 2007 series Living with the Kombai Tribe: The Adventures of Mark and Olly (BBC/Discovery Channel 2005; Cicada Productions/Travel Channel 2007; see also Hoesterey 2012). Similar programs have since been made by crews from Finland, France, Germany, Italy, Slovakia, Australia, Switzerland, Brazil, Vietnam, Japan, Denmark, Korea, Spain, Vietnam, Hungary and Slovenia. Korowai treehouse construction was the culminating sequence in the 'Jungles' episode of the 2011 BBC blockbuster series Human Planet. Photos of Korowai are featured in Sebastião Salgado's Genesis 
project that has been circulating internationally in prominent exhibition venues since 2013, and in the heavily publicised Curtis-style project of Jimmy Nelson titled Before They Pass Away (Salgado 2013: 136-49; Nelson 2013).

The power of foreigners' experience of Korowai as primitive flows from an array of attributes that they project onto Korowai or selectively emphasise about them, and that reinforce each other in an overall feeling of coherence. One focus is treehouses, which activate more general primitivist ideas of animality, closeness to nature, childhood innocence and cultural primevalness (Stasch 2011a). Media representations especially play up cannibalism, while tourists at large dwell on themes of violence and danger. Above all, visitors are concerned with the idea that Korowai are isolated from the global consumer economy, produce their livelihood directly from their forest surroundings, and have not previously seen whites. All these motifs intertwine with an idea that Korowai have not changed across time, and incarnate a deep past of humanity at large. Many of the different motifs are concretely summed up in nudity. Absence of imported clothes is the most prominent issue tourists attend to in judging specific Korowai people's match to a primitivist ideal (Stasch 2014b).

The character of the primitive as a collective representation with a life of its own in tourists' societies is particularly clear from regularities of their discourse that poorly match actual Korowai lives. Tourists and media professionals regularly identify Korowai as 'hunter-gatherers', even though there are domesticated pigs and large banana gardens right beneath their houses, and the sago stands providing their staple food are anthropogenic. Tourists commonly describe specific elderly men as 'chiefs', just as Darmono used the Indonesian expression kepala suku 'tribal chief'. Yet there are no endogenous-named leadership roles in Korowai life and no tendencies of gerontocratic authority. A more complex example is the rise of the English-language phrase 'Stone Korowai' and its Indonesian analog Korowai Batu, used as ethnic designations for Korowai who live in an upstream direction. During the 1990s and early 2000s, upstream Korowai were understood to be less contacted by outsiders than their downstream counterparts. There is no Korowai-language expression meaning 'Stone Korowai' that is used to designate a subpart of the Korowai population. But in the 1990s when tourists repeatedly asked to meet Korowai who use stone axes, Indonesian and international tour guides, along with certain Korowai intermediaries, innovated the Indonesian-language expression meaning 'Stone Korowai', to talk about Korowai who live to the northeast. The expression took off as a floating designation that could be used for any Korowai whom tourists were seeking to meet, and who lived farther upstream than the downstream villages where tourists first arrived in the area. The expression is used by tourists and guides as if it is the proper name of a definite Korowai ethnic subgroup, but the category only exists in tourism and other new contexts of interaction 
with radical foreigners (like Darmono) in which there is pressure to identify a metonymic subpart more truly exemplifying the primitive type. The attraction of 'Stone Korowai' for outsiders is boosted by the way this label makes the iconic primitivist attribute of stone tool technology the very name of the people the outsiders seek to encounter.

Across the above-outlined tourism history, meanwhile, Korowai have acquired and performed an idea of their own primitiveness that is cognate to tourist primitivism, but that reflects distinctive Korowai cultural sensibilities about issues of social inferiority and superiority. Two patterns I will first explore are a cultural emphasis on material objects as the truth of relations, and an emphasis on meeting others on their own transactional terms. These are both exemplified, for example, in a response to tourists that Korowai widely report themselves as having, namely a desire to create exchange relations with the wealthy foreigners. As one woman said: 'When Whites first came, people were scared and took off. Now they say, "What will we give?" If we get money, we'll be happy. If we bring them produce and they buy it, then the sellers are happy'. This reaction of 'What will we give?' reflects feelings that exchange of material objects is the main question of social relations in general, and that the appropriate response to an encounter with people possessed of wealth is to try to get into the transactional stream with them by meeting their desires.

This pattern of seeking to meet tourists on their own transactional terms goes beyond objects to the staging of performances. A revealing detail here is widespread Korowai knowledge of the word asli, which in standard Indonesian means 'authentic, original, indigenous, primitive'. Through tour guides, Korowai have learned this word as a description of the people tourists seek to meet, but what Korowai understand asli to mean is simply 'nude', in the sense of not wearing imported clothing. Korowai say that tourists come to visit them because they want to see people who do not have clothing but instead wear fibre skirts, rattan waistbands and leaf penis wrappers, since the tourists have never experienced such conditions before. The Korowai focus on material objects here is parallel to tourists' own material focus: tourists actually are intensely scanning Korowai bodies for the material signs on them. And yet for tourists, material objects and the visible condition of nudity are penumbral to a larger spiritual or metaphysical presence that primitive humans are thought to incarnate, while Korowai are disarmingly direct in locating the significance in the material conditions themselves.

The most common way Korowai seek to meet tourists on their own transactional terms is to hide away factory-made clothing and other imported manufactured goods shortly before tourists arrive, much as in the Gary Larson 'Far Side' cartoon showing two islanders hiding away their TV and VCR while anthropologists approach. This staging of an appearance of primitivity would be morally 
disturbing to tourists and their compatriots, who interpret actions through a cultural obsession with 'authenticity' or 'sincerity' (Trilling 1972). The staging does not trouble Korowai, who instead say that what would be immoral is not presenting tourists with the experience they have been led to expect. Hosting tourists, Korowai also allow the visitors' desires to organise what activities the Korowai hosts will carry out for the time the tourists are present. Yet these ways of relating to tourists' presence are not radically different from Korowai people's strong concern in relations among themselves with solicitousness to the other's distance. For example, feast transactions involve elaborate work of feast owners managing appearances and communications with invitees, to try to bring about an eventual exchange of food for dance performances, across gaps of geography and political independence (Stasch 2003). The transactional outcome of the feast process is the truth of that process, rather than the relation being riven by anxieties of authentic meaning different from appearances.

Running through the 'What will we give?' response to tourists is a more basic stereotype of tourists as wealthy, which is also a good illustration of the Korowai focus on material articles as the truth of persons and their relations. The stereotype of tourist wealth is based partly on direct observation of tourists' objects and money during their visits. But the stereotype also plays out in the further form of a model of tourists' home country lives, according to which the foreigners consume piles of food and money that are 'just there' (xondüp) in their houses. This is a canny long-distance insight into the organisation of capitalist consumer culture, but also an inverted projection of Korowai people's objectled focus in understanding social relations, and their ambivalent sense of the defining centrality of outdoor toil in their own lives.

Fantasising the tourist other as living in an unalienated material utopia of readyto-hand consumables, Korowai also reverse the evaluative hierarchy of their past first categorisations of foreigners. In a common cross-cultural pattern, Korowai refer to themselves ethnically by two synonymous words meaning 'human' (yanop and mayox). Prior to new foreigners' intrusion over recent decades, these words stood in relations of paradigmatic contrast with proper names for neighbouring ethnolinguistic groups, but also with the term laleo, which designates a nonhuman demonic monster people are thought to become after death. Korowai conceive these monsters as an ethnic population. They think the demonic dead are repulsive and dangerous, and they regularly experience these monstrous dead as intruding into living people's lives. When Whites, Indonesians and strange Papuans started intruding in the 1970s and 1980s, Korowai called them all the 'demonic dead', and initially thought of the intruders as non-human, by contrast with Korowai people's own resolutely 'human' selves. This 'human' versus 'demon' ethnic polarity was highly pejorative toward the foreigners. But with the rise of discourses of foreigners' utopian material conditions, Korowai 
have gone from being a superior 'human' centre in contrast to an inferior periphery of the demonic dead, to the reverse situation of even referring to themselves as 'not human', in contrast to a superior centre elsewhere. The fact that 'human' and 'demon' already existed as a hierarchical framework for thinking about ethnic difference helped make this primitivist way of thinking familiar in advance, even though the primitivist formation radically reverses earlier evaluations.

These evaluative dimensions of Korowai orientations to tourist wealth also involve a further broad cultural sensibility that has shaped Korowai performances of themselves as primitive, namely an ethic of valuing self-deprecation in exchange. When I ask Korowai why tourists come visit, they sometimes say it is because tourists have heard that Korowai live without money and articles, and so out of love and pity the tourists come to divide out these things to them. As one man put it, 'We [Korowai] live here empty handed, and so they say "You people are without articles", and they come divide out to us.' This representation is half accurate: it is true that tourists come because Korowai lack articles, but it is not part of tourists' self-understanding that they therefore visit Korowai in order to give them the articles they lack. In Korowai kinship, though, it is a prototypic act for one person to be lacking in articles and another to be moved by pity and love to give something to him or her. This is the model Korowai project onto tourists when they imagine the foreigners come for the express purpose of giving articles. On this understanding, there is a relation-making value to emphasising one's baseness. Under an egalitarian ethos, to put oneself down can be to ask for a relation. Claiming inferiority means not claiming to stand out as better than other people, but instead putting those people in a position of being moved by one's own deprivation to share wealth and create equality.

\section{Performing the primitive toward government officials}

This ethic of self-lowering, along with the focus on material objects and on meeting others on their terms, are amply apparent also in Korowai selfprimitivising performances toward state actors. Missionaries were more important to Korowai than government personnel in the 1980s, and tourists were the biggest foreign presence across the 1990s. But engagement with state actors has recently intensified, and the primitivist formation that Korowai first developed in tourism contexts has migrated to relations with the state. While Darmono's helicopter visit to Danuwage airstrip was novel in both the elite level of officeholder it involved and in his actual travel to the Korowai area, the encounter followed a script that has circulated widely among Korowai since 
about 2005, albeit more as an idea than a directly enacted reality. As Korowai anticipate them, these encounters focus on the figure of a 'Big Head' or 'Big Boss' (xabian-tale), a new term for all government officials. ${ }^{5}$ Or the encounters focus specifically on the figure of a Bupati or 'Regent', who in the Indonesian hierarchy is the head of a Kabupaten or 'regency', between the higher level of 'province' and the lower one of 'subdistrict' (ecamatan, distrik).

For example, in 2007 a woman told me about work of grass-cutting undertaken by residents of a village who had heard that the Bupati was going to come visit. She explained, 'The Bupati will come and everyone will dance celebratorily. These women [the speaker's friends] will take off their clothes. They are doing the work because the Bupati will see it.' I asked her what a 'Bupati' is, to which she replied:

We haven't seen. We don't know. But we take hold of this work, and he'll come, and divide out money, and we'll get clothes. They [Korowai] dance in formation and they [government officials] regularly pay them. The Bupati is going to pay for the work and the xasam [genre of martial dance]. He will see that these people live without money and he'll divide it out. He'll say, 'What money will they buy clothes with? It's rather like forest, it's rather like it's not even a village. They don't know razor blades and fishing line, shorts and shirts, rice and noodles, steel machetes and axes. I'll give them money, and they'll make the village big.'

Another person quoted a visiting Bupati's expected self-account by referencing the split rattan loops that are metonymic of male traditional dress: 'I came for waistbands,' the visitor would explain.

No local village has ever actually been visited by a Bupati from any of the four regencies with jurisdiction over different parts of the Korowai lands (following subdivision of Merauke into smaller units around 2003). But the model these speakers articulated is widely held among Korowai, and underpins their frequent state of expectation toward the prospect of official visits. ${ }^{6}$ At its centre is an

5 The Korowai word xabian 'head' was not formerly used to designate roles of leadership and authority, which did not exist in their society. But it has come to mean 'boss' across the period that Korowai have become familiar with power structures characteristic of state and commerce. In this usage, the Korowai word is being used as a loan translation of Indonesian kepala 'head', as in the government-underwritten office of kepala desa 'village head' (see Stasch 2014c:85-90).

6 Another example of this state of expectation unfolded when I was in the Korowai area in August 2011, staying at a feast site with some German tourists. As the feast's peak grew near, a problem arose with one of the large performance troupes expected to travel to the feast site. The village of Yaniruma lay about ten miles from the feast site, and a rumor circulated that the Vice Regent was going to come to that village by airplane just one day before the feast. Everyone in that direction gave up their plans to travel to the feast, and instead went to Yaniruma. The Vice Regent in reality visited a day earlier than rumored, and stayed for only an hour. Most of the people who travelled to Yaniruma to welcome him thus arrived after he had left. They were not ready to travel back the way they had come to attend the feast, and so the feast performance troupe from that part of the landscape never materialised, to the embarrassment of those who had planned it. For an example from 
idea that performing primitivity and deprivation toward a wealthy foreigner will emotionally move him to want to give them objects they lack. The model also involves dense interconnections between nakedness, the aesthetics of coordinated celebratory and martial dancing, lack of commodities, the contrast between 'forest' and 'village', and the telos of a village becoming 'big' (a Korowai idiom for what outsiders would call 'development', and a condition Korowai see as the opposite of naked primitivity). This model also underpinned Korowai performances toward Darmono at Danuwage.

Korowai expectations about this type of encounter have been influenced by earlier experiences with tourists, and by even older practices of spectacular encounter among Korowai themselves at feasts. But their expectations have also been fueled by knowledge of rituals of state-society articulation at distant administrative centres. Around 2005, for example, 20 Korowai and Kombai men performed dance formations in traditional dress for a visiting Bupati at the village of Boma about 30 miles south of the Korowai area. The Bupati was a Wanggom man originating from the next river system east of Korowai. He briefly danced in the midst of the Korowai and Kombai performers, and he gave them 5 million rupiah (more than US\$500). In another common kind of event, in 2001 two old men and a younger relative travelled 200 miles to Merauke to seek an audience with the Regent then presiding over their area, in the expectation that the older pair's primitivity would elicit chainsaws and outboards. They told the Regent that their village is small and the Regent needs to tell his functionaries to come make it big. This Regent was again a southern lowlands Papuan, and he shed tears at the old men's resemblance to his own parents, before giving them gifts of cash and equipment. As one person narrated, '[The old men] went to Merauke in just leaf penis foreskin wrappers, and [the Bupati] was wracked by longing/sympathy and gave them two outboards.'

These encounters involve the intersection of different models of transaction across hierarchy respectively held by Korowai and by government officials. Such intersections are occurring with much greater frequency amidst the already-noted shifts in governance now unfolding across Papua. The Bupati for whom Korowai danced in Boma was the head of the newly created Boven Digoel regency, seated far closer to Korowai than the previous capital of Merauke. ${ }^{7}$ This man, Yusak Yaluwo, was said to be related to Korowai on his mother's side. As one Korowai

another part of Indonesia of the external figure of the Bupati being placed at the centre of local community life, see Allerton (2003). I have elsewhere discussed the circulation of the exogenous figure of the 'police' as a verbal representation with a life of its own among Korowai (Stasch 2001). The figure of 'tourists' (tulis or sulisi, from Indonesian turis) also has a vigorous discursive life as an ethnic type even among Korowai who have not encountered any of them directly. Korowai orientation to 'heads' or the Bupati figure specifically is another variation on this pattern.

7 The new regency is named after the notorious Dutch camp for anti-colonial political prisoners that had been sited at this location in the 1920s and 1930s. The camp history is a major early wellspring of discourses of isolation and primitivity attached to this specific region of New Guinea. 
person narrated Yaluwo's sentiments upon seeing them perform, 'Korowai are my people,' he said. 'They are rather asli people with rattan waistbands, they are naked' (Kolufo-fe nayanop dabo. ango asli lenoptabulmananop, aifoyum yanop). The text and photos of a political biography produced for Yaluwo's 2010 re-election campaign repeatedly portray scenes of him visiting outlying settlements of constituents, where he is greeted by traditional dance performances (Wahyudi 2010: $8,17,23,28,32,122$ ). The book also refers to him in passing as 'this best son of Papua who still has the hereditary blood of treehouse descendants' (p. 42), and the cover features the motto 'I come, see, listen, cry, and decree', referring again to a transactional script of a powerful outsider being moved by his constituents' primitive baseness to confer wealth on them. ${ }^{8}$ In the event, Yaluwo was indeed re-elected by a strong majority to a second term, but only while being held in jail in Jakarta on charges of misappropriating the equivalent of US $\$ 7$ million. ${ }^{9}$ His example is extreme, but throughout rural Papua today electoral popularity among the rural poor and clientelistic disbursement of money are two sides of a coin. There is an accidental synergy between the clientelistic logics of this state form, trans-ethnic Papuan sensibilities about giving and kinship that flourish and mutate in the new government contexts, and the Korowai sensibilities about relating to wealthy foreigners we have already seen structuring performances toward tourists.

These Korowai sensibilities are what I am most interested in. Performances toward government officials (like the giving of artifacts to Darmono) again reflect a focus on material objects as sites of the truth of social relations and personal being, and reflect a conviction that the way to deal with radical others is to transact with them. We additionally see in these performances something I did not emphasise before that is also present in relations with tourists, namely great ambiguity in the power dynamics of encounters, even when the transactions involve apparent self-lowering. To the extent Korowai do understand themselves as manipulating appearances to meet tourist desires and get money or other articles, this involves a sense of occupying not only a position of inferiority but also one of winning in transactions, akin to the understanding of 'raiding the land of the foreigners' described by Rutherford (2003). Such ambiguity is even clearer in performances toward government officials. Martial dancing in elaborate festive decorations, with bodies bare of imported cloth, is an enactment at once of primitive baseness and of the power to compel emotional responses of fear, awe or longing.

8 The quoted expressions are 'putra terbaik Papua yang masih memiliki darah titisan keturunan rumah tinggi ini', and 'Saya Datang, Melihat, Mendengar, Menangis, dan Memutuskan'.

9 See for example 'Graft suspect wins reelection in Papua', The Jakarta Post, 8 September 2010 www. thejakartapost.com/news/2010/09/08/graft-suspect-wins-reelection-papua.html, and 'Regent gets 4.5 years in prison for corruption', The Jakarta Post, www.thejakartapost.com/news/2010/11/03/regent-gets-45-yearsprison-corruption.html (both accessed 3 November 2013). 
But it is the pattern of self-lowering that is clearest of all in meetings with government officials. Here as in tourism, new Korowai practices of interethnic relating toward wealthy foreigners follow a prior sensibility that portraying oneself as deprived is a way to create valued relations of care, thanks to the compassion it elicits in others. Recall that the emblematic objects that Korowai gave to Darmono were meant to make him 'join in experiencing our people's hardships'. From these objects he was supposed to know in his own emotions how impoverished Korowai are in their material lives, by comparison to his wealthy life of ease. The scale of economic inequalities between Korowai and the new foreigners is unprecedented. Also new is the primitivist framework the outsiders bring to the encounters, that Korowai quickly learn. But inequality as such is not new. Hamming up their primitivity and deprivation toward state officials, Korowai adapt an earlier mode of engaging with inequalities in kinship life to the greater inequalities of the new economic order and the new hierarchy of primitive and civilised.

Variations on the sensibilities about equality, emotion and exchange that have shaped Korowai uptake of a concept of the primitive are widely encountered elsewhere as well. A perception of institutional abandonment is said to be felt all across peripheral areas of Indonesian Papua (e.g. Anderson 2012, 2013b). The pattern is also common in independent Papua New Guinea. Hoenigman (2012: 291) reports of Awiakay villagers on a Sepik tributary:

People often say in the lingua franca Tok Pisin, mipela las ples bilong bus, 'we're the last place in the bush'. Awiakay often complain that they are 'inferior' and 'forgotten', not only in comparison with the white man (TP waitman) or PNG town dwellers, but also in comparison with neighbouring groups. This is a common feeling among those Papua New Guineans who are far from roads, shops, health centres, and governmental offices. [footnotes omitted]

This sense of having been passed over by economic prosperity prompts feelings of inferiority or what some authors have termed 'humiliation', and intense desires for change (e.g. Leavitt 2005; and other studies in Robbins and Wardlow 2005). Several ethnographers of PNG societies have described primitivist pageants and slapstick parodies of old time practices performed for mining company representatives or government officials (e.g. Robbins 2006, 2009; Knauft 2002, 2007). These pageants and other representations of humiliation cannot entirely be explained as introjection of hierarchical superiors' actual disdain for rural New Guineans, on the model of Fanon's analysis of black consciousness under white colonisation (2008 [1952]). There is additionally at work a cultural concept of the efficacy of expressions of deprivation in eliciting relational engagement from the powerful. Knauft (2002) writes of a paradoxical pattern of 'recessive agency', according to which Gebusi seek to bring about desired sociocultural 
transformations by occupying positions of passivity relative to others (a pattern also carefully elucidated in a different context by Wardlow 2006, under the label 'negative agency'). Korowai attraction to the idea of an abstract external figure of power and generosity such as a Bupati or 'Tourist', their expressions of dismay about administrators failing to deliver quickly on promises of making local villages 'big', and their strategies of self-lowering as a way to elicit relations are thus cultural patterns with deep regional resonance.

But allied patterns are apparent in many other communities worldwide, in which people struggle with experiences of deprivation. Writing about southern Africa, for example, Ferguson (2013) has noted that while active seeking of relations of dependent subordination is disturbing to emancipatory liberalism, such relations of social inequality may involve more security, freedom and well-being than the alternative of what Ferguson calls 'asocial inequality'. Conversion of 'asocial inequality' into 'social inequality' is a reasonable gloss for what Korowai are seeking in their performance of primitivist imagery toward government officials.

\section{Bootstrapping out of the primitive by sending boys to school}

The final ethnographic topic I will examine is Korowai boys travelling to faraway towns to go to school, often at the urging of their kin back home. This pattern still involves self-lowering in the terms of a new primitivist hierarchy, but also a stance of assertive effort to reposition oneself from an inferior pole to a superior one.

Before turning to this actual practice, though, I should pause to flesh out the domestic Indonesian primitivist structures within which Korowai now live, so that we can more fully appreciate the pressures to which schooling migration is most directly a response. So far I have emphasised continuities between primitivist frameworks structuring Korowai interactions with government officials and with tourists. But while these formations are historically connected and continue to intersect and overlap, there are three tendencies in the domestic formation that might importantly set it apart from the international one.

First, in the domestic formation the evaluative stance toward the primitive tends to be more pejorative than in contemporary international primitivism. It is a nearly universal feature of primitivist models that they are evaluatively volatile, and that positive and negative stances intermingle in them. Still, as a matter of proportions, contemporary international media and tourist interest in Korowai is at least on its surface dominantly positive and Romantic in tenor, 
where Indonesian primitivist evaluation of Papuans is dominantly critical. This is amply reflected, for instance, in the basic terminology of state development policy from the recent past. It is well-known that in the 1980s and 1990s, people at the fringes of the Indonesian state's reach were officially categorised in baldly pejorative primitivist terms as 'estranged/wild tribes' (suku terasing), who were 'backward' (terbelakang) and needed state agents to 'make them human' (memanusiakan) through a civilising process of state integration, sometimes only slightly subtler than the army-led campaign of 'Operation Penis Gourd' (Operasi Koteka) imposed on Baliem Valley Dani in the early 1970s and formally inaugurated by First Lady Tien Suharto. Traces of this heritage of emblematising people like Korowai as the polar opposite of a positively evaluated national ideal of socioeconomic development persist to the present (as is evident from Darmono's earlier-quoted statements), even as the official primitivist language has been softened from 'Wild Tribes' to 'Geographically Isolated Customary Law Communities' (Komunitas Adat Terpencil) (see Duncan 2004, 2007).

In popular consciousness, particularly among the more than half of Indonesians living on Java, there have long been strong currents of prejudicial racialisation of Papuans as fearful subhuman inferiors (e.g. Anggraeni 2011: 73). Many Papuans are highly attuned to this prejudice and its primitivist garb, as in the following statement of a Papuan man studying in Java to become a civil servant, supported by Special Autonomy funding: 'To separatist Papuans, I am a traitor. To most of our Javanese teachers, I am a monkey they are trying to lure down from the trees. I just want to feed my family' (quoted in Célérier 2010; see also Hastings 1982: 159; Rakhmani 2012; and Munro, this volume). Illustrations of a contrary evaluative stance are also easy to find, of course. For example, the branch of the Indonesian state that officially defines categories like 'Geographically Isolated Customary Law Community' and is charged with provisioning of special services to them is the Department of Social Affairs. This agency's first brief initiative in the Korowai area in 1986 unfolded in coordination with the activities of Dea Sudarman, a New York-raised Javanese documentary filmmaker and art collector, who had already taken a strong positive interest in Asmat art and culture and who has continued to make her experiences in Papua integral to her cultural projects in Jakarta (see e.g. Sudarman et al. 1986). With the dramatic expansion of Indonesian middle class consumer culture in the 2000s, media primitivism within Indonesia has now partially re-converged with international trends, as reflected in a recent spate of domestically produced television travel show episodes with titles such as 'Hidden treasures of the Korowai'. ${ }^{10}$ Still, the resolutely pejorative character of popular primitivist imagining of Papua is better exemplified by the mainstream

10 See for example the two episodes of Trans7's travel show Adventurer's Footsteps (Jejak Petualang) available at us.m.mytrans.com/video/2013/01/04/49/17/27/7632/rumah-pohon-suku-korowai and us.mytrans. com/video/2012/06/27/49/17/27/5294/harta-tersembunyi-korowai and the two similar episodes of the same 
2011 Indonesian-language feature film distributed under the English title Lost in Papua. The 'Korowai' tribe appear centrally in this film, as noble savages among whom the female Javanese heroine has an idyllic sojourn. But later this positive primitivism is heavily overshadowed by the same heroine's lengthy sexual imprisonment by a neighbouring all-female tribe of cannibals, who communicate only by grunts and hoots, and from whom she is finally rescued by a virtuous Korowai warrior. ${ }^{11}$

A second major difference between domestic and international primitivism is also apparent from materials I have already outlined, namely that domestically the primitivist model is also a trajectory of desired historical transformation. The primitive is the opposite not just of civilisation but also of development. Giving up treehouses, forming villages, ending cannibalism and converting to Christianity are one and the same with state and market participation, and with entry into a teleology of advancement and progress. In international media and tourist primitivism, primitive purity is centrally under threat of loss, but this is conceived as extraneous to the idea of the primitive itself. In the regional geopolitical world primitivity is instead a reason for transformation.

Third, in the domestic and regional formation, primitivist ideas are lived materially in the geopolitical and institutional order of the landscape, as much as verbally in abstract discursive models or via visual media like photography and television. For example, primitivist ideology is lived in physical movement between a population centre where there is vast monetary wealth and an outlying hinterland where there is not, or in the presence in a village of ministers and schoolteachers. This physicality of the primitive is intertwined with my point about transformation. Across much of the southern lowlands of Papua, in the talk of Dutch, Indonesian or Papuan outsiders, and very quickly that of local populations, 'coming down' from treehouses and aggregating together in permanent villages has been understood as a watershed historical transition (Wamafma 2008; Schoorl 1993), and the transition is strongly aligned

channel's My Indonesia (Indonesiaku) available at us.mytrans.com/video/2012/07/03/50/52/154/5333/ menembus-rimba-papua-menuju-suku-pedalaman, and us.mytrans.com/video/2012/07/04/50/52/154/5349/ mengenal-lebih-dekat-suku-korowai-di-pedalaman-papua-.

11 See www.youtube.com/watch? $v=$ NC2jElqyebc (accessed 15 March 2013). The filmmakers took inspiration from an urban legend that widely circulates in Papua about a society of women who reproduce by having sex with men who stumble into their midst, before killing them and any male progeny. Many accounts locate this society in the Mamberamo River basin, but it has also been previously tied to Korowai (The Jakarta Post 1991). The idea of a society of women who kill their male young has been reported from other parts of Indonesia since at least the early 1500s (Reid 1994: 271). In the film crew's production process, the closest they came to the Korowai lands was Boven Digoel 50 miles to the southeast. It was Papuans from this administrative centre (including the head of the local Bureau of Culture and Tourism) who performed the 'Korowai' roles. Korowai who heard of this arrangement when the film later circulated in Papua on VCD expressed anger toward those who had impersonated them, arguing that they alone are the ones whose place it would be to perform such actions. The film was never distributed theatrically in Papua, having drawn critical anti-primitivist Papuan commentary in newspapers following its very successful release in Java. 
also with other iconic contrasts between practices coded as archaic and ones coded as contemporary: between nudity, piercings and scarification versus clothedness and lack of facial ornaments; between cannibalism versus living together peaceably; and so forth. All of these material signs are also central to the primitivism of international tourists and Korowai adaption to it, as we have seen. But as a matter of proportion, I would suggest that on domestic scales the primitivist framework is lived even more at semi-discursive levels of the total physical organisation of life, by comparison to the relatively more verbalised and performatively set apart character of primitivist moments in tourism.

A further important correlative of this 'total' character of the domestic primitivist formation is that it is not a thoroughly state-associated framework of evaluation, nor a framework aligned in a simple way with Indonesian immigrants' political and economic domination of Papuans. In the Indonesian and Dutch colonial eras alike, church workers, government functionaries, schoolteachers and other outsiders who introduce primitivist ideas to local populations have been themselves Papuan. Even more consequential are ways that primitivist frameworks of categorisation circulate and grow horizontally, among local Papuan landowners.

As Korowai move through the contemporary political geography of primitivism and learn regionally circulating ideas of an overarching hierarchy of places and human conditions, they have more contexts of life in which they think of themselves as occupying an inferior social position to other people. There are many specific actions they take in response. But perhaps the area of activity where the primitivist framework stands out most starkly is seeking of social advancement through children's education.

Elementary schools have operated sporadically in two southwestern Korowai villages. But most students who attend any school, and all who go beyond six grades, do so by living in towns or large villages anywhere from 20 to 200 miles distant from the Korowai lands. It is almost exclusively boys who migrate for schooling, due to parents' fear that girls would be a focus of marital and sexual advances by strangers, and adults' possessiveness toward their young female relatives' marital prospects and sexuality. ${ }^{12}$ There are now at least 50 Korowai youths living in a dozen different towns to attend elementary school, middle

12 The only exceptions are two girls from Mbasman village who in 2009 began attending elementary school in Sentani, 200 miles from home, at about age 10. The conditions enabling this included that government staff from the Department of Social Affairs acted as mediators, and it was known that they would live in a femalesupervised 'orphanage' for rural girls (originally established by an expatriated Belgian Catholic nun). One of the Korowai girls, though, was brought back to the Korowai area by her father in early 2014, when news circulated that she was no longer living in the dormitory. While men have been more mobile than women in the new era of regular Korowai travel far from their own lands, a colourful counterpoint was expressed by one woman who was telling me about the many different Korowai clan territories to which women from her natal patriclan had moved upon marriage: 'They live all over the place, like foreigners!' (xofaxa bau wofaxa bau, 
or high school, or university. What is striking is the single-mindedness with which these boys and their relatives see schooling as a goal, to the point of enduring severe emotional and financial hardships to make it possible. Boys themselves are often hungry in town, and may stay out of school for long periods due to lack of money for fees or uniforms. Their relatives send them the little money they ever scrape together through income opportunities arising back home. Persons on all sides suffer painful separations, including during crises of illness or death. This extreme parental enthusiasm and self-sacrificial striving in relation to children's education is common throughout rural Papua (see Munro 2013: 26). It is a frequent way that peripheral rural populations worldwide engage with national or global political geography (e.g. Killick 2008).

The most basic Korowai idea motivating this migration is that schooling is how a child can gain any foothold in the system of salaried occupations. Kin want boys to go to school so that they will come back as a Regent, schoolteacher, pastor, soldier, health nurse, policeman or civil servant, a pattern of aspiration again widely attested worldwide (e.g. Pigg 1992: 511). These salaried jobs are roles Korowai routinely lump together under the general term 'head' or 'big head' (xabian, xabiantale, see note 5). In a typical statement, one man told me that the purpose of boys' schooling is 'So they will become big heads' (xabiantaleleloxate). ${ }^{13}$ People also routinely express this goal of gaining a civil servant position or other salaried employment using the Korowai-language expression 'become human' (yanoptelo). This usage is a loan translation of the Indonesian-language phrase menjadi manusia that also means 'become human', widely used by other Papuans in the region to talk about securing salaried jobs. ${ }^{14}$ While the core force of this new Korowai idiom is better translated by the English expression 'become somebody', there is a basic implication that people who lack salaried employment are less than human. The Indonesian and Korowai expressions 'become human' used in this way thus chillingly echo a history of Indonesians with military, political, or commercial power over Papuans deprecating them as not 'human' (manusia). The Korowai expression also echoes and inverts the earlier Korowai ethnonymic pattern of using their vernacular term yanop 'human' as an ethnic self-designation, and the term laleo 'dead non-

\footnotetext{
laleo-alin ülop). When I asked what she meant by this, she explained that part of the work arrangements for schoolteachers is that they are assigned to job postings in villages far away from their home ethnic territory. She was likening women's experiences of virilocal marriage to this pattern.

13 Desire for schooling and civil servant positions played a central role in the Naomi Robson affair of September 2006, though this was completely hidden to the foreigners involved and their media audiences. In this affair, an Australian tabloid television personality set out unsuccessfully to 'rescue' a small boy named Wawa who was purportedly a Korowai orphan in danger of being killed and eaten as a witch. Her failed mission became the focus of an extended national media firestorm in Australia. What Korowai and Kombai all understood, though, was not that Wawa was a witch but that his relatives wanted to get him out to school. 14 In Indonesian there is an alternative term orang 'person' that does not focalise the human/subhuman boundary in the same way as manusia 'human, humanity'. But among Korowai and people of neighbouring ethnicities in the southern lowlands, it is menjadi manusia that I have heard, in talk about civil servant posts.
} 
human demon' as an ethnic designation for nonlocal foreigners. People also sometimes narrate the purpose of boys' schooling using expressions such as 'So he will become a foreigner' (laleoimbanteloxai, literally 'become a member of the demonic dead ethnicity') or 'For our people to become like Whites' (noxumayox xalxeyoanopüloptelongalxe) using a new phenotype-focused phrase referring to whites as light-skinned. These expressions are loosely synonymous with saying the boys will 'become human' or 'become a big head' (compare Rutherford 2003; Bashkow 2006).

What all these expressions centre on is the utopian vision of an alternative economic regime that Korowai identify with city-dwelling whites, Indonesians and Papuans, and that we have already encountered in the idea that tourists live from food and money that is 'just there'. From travel to administrative centres outside their lands, Korowai have added to the imagery of tourists eating from endlessly self-replenishing stocks the further observation that civil servants sit in their offices all day, are paid money, and live from consumer goods they buy with that money. The main reason Korowai want access to the system of salaried occupations is this lifestyle of what one man described to me as 'getting articles nicely' (folulto misafi fongalxe).

In contexts of interethnic encounter, Korowai further experience themselves as occupying an inferior position in a hierarchy of human worth around a diverse array of bodily practices, beyond the core focus on salaries and food. A recent book by an Indonesian anthropologist recounts one Korowai man's discourse:

Marthen Hanai ... told of his experiences when he went to the town of Kepi. He saw people like civil servants wearing official uniforms, health workers who wore white clothes, and school-aged children going to school. He became sad because there is no possibility for him and the people in Basman village to have such opportunities, because schooling does not operate there the way it should, because they cannot read, and because they cannot count well. [He said:] Despite that there are still many of us who are now naked and there are still those who live up in high trees, we also wish that one day our children could live making use of clothes that are fine, clean, and neat. We also wish that our children could later bathe using sweet-smelling soap, and brush our teeth like city people (Lekitoo 2012: 105-106).

This pattern of experience is common all across Korowai society today.

Concerning how school attendance is actually supposed to lead to salaried employment, one Korowai focus is fluency in Indonesian, and especially the ability to read and write. Korowai also say that it is by being in school away from their home places that children's 'thinking' becomes 'brilliant, clear' 
(dialun), such that they can operate successfully in social contexts of commerce, government and Indonesian speech. Korowai reason that adults who have been fully socialised in their home location are beyond the ability to acquire these skills, and instead need educated children to come home as 'big heads' and tell them how to reorganise their lives. In this way, Korowai articulate an explicit model of the inculcation of new forms of consciousness as a result of living amidst specific institutions. Characteristically, they intertwine that model with ideas of reproduction, or the connection and disparity between relatives of different generations. Faced with their own position of perceived inferiority in a new economic system, Korowai turn to what they are good at, kinship, to crack the problem of what they do not have, the new urban wealth and access to state and market institutions from which this wealth flows.

This turn to the traffic in children as a resource for dealing with history is also apparent in the most common of all ideas that relatives bring up when asked about schooling migration. In a very recognisable New Guinean pattern, relatives of a boy in school frequently say that their intention is to benefit from the 'yield' or 'produce' of the boy after he has attended school and gotten work, as reciprocation for the care they have earlier put into him. For example, when I asked one woman whose son was away at school how she felt about their separation, she said she did not mind, because she occasionally takes sago and pandanus to the boy at his place of schooling, and after he becomes literate he will get money from his own 'head' or 'boss' and give her rice, noodles and clothing, which she currently lacks. Or as one woman narrated the general idea of sending boys to school, 'Let's eat the produce of their hands!' (yexenep melxaluxx lafen). The idiom 'yield of hand' or 'produce of hand' (mel-xalüx) is here adapted from its earlier use to talk about a basic moral norm of intergenerational care, according to which people who give children food when young will receive the game meats, sago starch or other bounty the child procures upon becoming an adult. $^{15}$

15 For both the older institution of parents enjoying the produce of mature children they have earlier fed, and the new one of hoped-for return from boys' schooling, bilingual Korowai translate xalüx by the Indonesian term hasil 'produce, effect, profit' (see Munro 2013: 33). I have also heard people refer wryly to children's traditional obligation to give game or vegetal produce to their elders as tugas, Indonesian for 'duty', strongly associated with salaried occupations. The term 'yield' (xalüx) has further collocations besides mel-xalux 'yield of hand' designating other transactional forms of kinship debt and recompense across time, such as lal-xalüx 'girl yield, bridewealth'. An example of bridewealth issues themselves intersecting with the schooling model was the decision of one bereaved widower in 2005 to take his two sons to Boma 30 miles south of the Korowai area and install them in school there (living with foster-parents from another Papuan ethnic group). He was prompted in part by his reasoning that his wife's death had left him not only emotionally bereft but materially impoverished, due to having given all his possessions away to his wife's relatives as bridewealth. Thus later he would eat the 'yield, produce' secured by his sons borne of the deceased women, after they went to school. Across the years of his sons' residence in Boma, he has regularly travelled there with forest produce and with money earned from tourism, to contribute to the boys' maintenance. 
This use of moralities of parent-child debt to try to gain a place in an alien geopolitical system is a first major way that schooling migration aligns with my claim that Korowai live out the new primitivist ideological formation in forms given by their egalitarianism. They live the hierarchical relation between the new and old economic systems in terms of kinship, and specifically in terms of an egalitarian norm of transforming asymmetries in people's capacity to care for themselves and others at different stages of life into an overall symmetric reciprocity of care across time.

After 20 years of educational migration, there is only one clear example of a Korowai man with a salaried government job, and nobody has been posted back to the Korowai area with such a position. Many boys have completed some schooling and then remained in town locations with tenuous economic prospects, or they now bounce between their home region and a town where they have formed ties of patronage, manual labor or courtship. The cohorts of boys who today continue to work their way up through different educational levels may be cannily pressing toward outcomes that will only be clear in another generation, or they may be facing a future of permanently fruitless sacrifices and frustrated hopes (Munro 2013; Sykes n.d.). But whatever the eventual outcomes, another significant pattern in people's reasoning is that they regularly explain their commitment to invest in schooling by citing cases of success from other Papuan ethnic groups. Korowai are highly aware of specific speakers of Kombai, Citak, or other neighbouring languages who work as teachers, civil servants and soldiers. Often Korowai describe themselves as feeling inferior to the neighbouring people who have achieved this, or they report being mocked by persons of neighbouring ethnicities who say things like 'You Korowai have stayed eating humans. You won't quickly have a subdistrict or get paid work. You should just stay there doing what you do with the tourists.' One man told me he sent his younger relative to school out of fatigue at Indonesian immigrants telling him that Korowai are illiterate. Awareness of neighbouring groups' success in gaining salaried positions can also take more affirmative forms, as in the extreme case of ex-Regent Yaluwo who is recognised as a relative who made it big from origins similar to Korowai people's current circumstances (though Korowai are not widely aware of his legal troubles). Often the ability to place boys in school at all depends on wider patterns of interethnic patronage and foster-kinship, whether across different Papuan identities, or across the divide of Papuan versus immigrant. The Korowai boys are taken in by members of other groups who have land, food, church or commercial resources at the schooling sites, or the boys live in dormitories on food bought with occasional funds provided by Papuan political patrons.

This embedding of schooling migration in issues of interethnic equality and care is a second and final broad way this area of Korowai activity follows the larger 
pattern of Korowai taking on primitivist ideology through their egalitarian values. The most direct spur to the schooling venture has been Korowai comparison of themselves to recognisable, proximate consociates. It is through a focus on relations of equality or deprivation in relation to ethnic neighbours that they pass into a larger formation of inequality and striving. Commitment to equality means that for Korowai to see other people living by a new economic system provokes intense desire to do the same. The experience of humiliation and desire in relation to ethnic neighbours' successes in the new system is a first form in which they take on the hierarchy of civilised versus primitive, lived in the terms of characteristically New Guinean concerns with equality and relational standing (Robbins 1994).

\section{Conclusion: Indigenous egalitarianism and exogenous domination}

Dean MacCannell, reviewing the film Cannibal Tours, puts eloquently a common turn of academic thought about primitivist interactions around the world today:

The film makes it painfully evident, the choice of the Sepik region drives the point home with precision, that this primitive 'Other' [of tourist-sending societies' popular imagination] no longer exists. What remains of the primitive world are ex-primitives, recently acculturated peoples lost in the industrial world, and another kind of ex-primitive, still going under the label 'primitive', a kind of performative 'primitive'. (MacCannell 1990:14)

And in fact, the notion of a "performative "primitive" does point toward the issue I have made my subject in this essay, the uptake of primitive stereotypy by those who are so stereotyped. Yet it would be a shame if the interpretive effect of this notion (or other widely encountered variations on it, in different language) were to end ethnographic inquiry, rather than serve as its beginning. I have shown here that the primitive is a kind of equivocal 'homonym' (Viveiros de Castro 2004) in an overall structure of working misunderstanding. Different parties to the encounter coordinate with each other intensely through this category, even as their understanding of the category's content and implications are systematically uncoordinated. The process of close social involvement between these different actors might flourish not just despite but because of the mutual misapprehension. And the concept of primitiveness that comes to be so central to Korowai actions toward foreigners is a sedimentation of closely intermingled endogenous and exogenous forces (compare Rumsey 2006). Primitivist ideologies enter into Korowai self-consciousness or are reinvented there under pressures of uneven access to wealth that replicate hierarchies of power and 
worth characteristic of a wider history of colonisations worldwide, within which the primitivist ideologies were originally forged. But the primitivism migrates and is reinvented also in the channels of culturally distinctive Korowai sensibilities about what social inequality is and how to respond to it or live with it. The ways primitivist ideologies enter Korowai self-consciousness or are newly elaborated there have been shaped by Korowai sensibilities about the importance of material objects as direct indexes of human worth and relational truth; their sensibilities about the urgency of getting into transactions with people who are alien and wealthy; their sensibilities about self-lowering as a good way of eliciting care and relatedness from others; their sensibilities about the ambiguity of power and worth in relations where one party appears to occupy the position of inferior; their sensibilities about the foundational character of kinship and generational succession as a resource for bootstrapping one's community into something different than it is; and their sensibilities about equality itself as a prime imperative of social existence. Many foreigners do not have those sensibilities as part of their primitivist ideas, or as part of their understanding of the ends of state order. Korowai gestures of what I have termed 'self-lowering' are being performed toward exchange partners who do not have the same kinds of answerability, empathy, shame and memory that animate the flow of goods among Korowai themselves. Yet the ways Korowai embrace and elaborate primitivism in their own terms seem very basic to the actual efficacy of primitivism as an ideology, in structuring social relations across differences of power and understanding.

The Korowai uptake of ideas of primitivist hierarchy is also tantamount to entry into relations of domination, and so my arguments in this essay also speak to the complexity of state power. Rutherford (2013: 7) asks in passing, 'What would it mean to tell the story of Indonesian colonialism as a tale of weakness, not strength?' The case examined here highlights ways that a society based on kinship, exchange, and an anti-hierarchical political ethos can be exceptionally vulnerable to entanglement with state power, and to certain forms of active participation in extending that power. The very levels of social life that state actors are oblivious of or indifferent to can be foundational to the strength a state holds in people's lives. The case I have examined is a paradoxical one of 'anarchist' egalitarians who are attracted to state power, and state institutions whose efficacy and amplification are partly dependent on non-state sociality.

The three ethnographic areas discussed across this chapter to make these general points have been quite varied, in keeping with a historical situation in which diverse institutional processes are unfolding and no single pattern can stand for the whole field. But the three areas compositely give an overview of Korowai people's condition of lived primitivism today. As a coda, I would like finally to sketch another recent sequence of events, in which all three of 
the ethnographic areas I have discussed happen to intersect. These events are centred not on Korowai but on a network of young men from the upper Digul River east of the Korowai area, who currently attend high school or university in towns near Papua's capital of Jayapura, or who have returned to the southern lowlands area after graduation. These young men are the kinds of neighbours whose educational and employment attainments spur Korowai people's own aspirations for advancement. Yet in the 2000s, these non-Korowai youths increasingly started referring to themselves by the new Indonesian-language ethnonymic expression 'Eastern Korowai' (Korowai Timur). By 2010, the young men began forming a cultural organisation for advancing their ethnic groups' political interests, and for mediating outsiders' access to their region. Before long, leaders described their organisation as having 130 members, from 43 subgroupings under the 'Korowai grouping in the broad sense' (suku Korowai besar). These leaders were identified in press reports as 'Korowai' persons, although they are at best speakers of neighbouring languages, from the same family as Korowai proper. By early 2012, the network's agenda was focused on creation of a 'Korowai' government regency, to replace the situation in which the territories of their ethnolinguistic groups are governed by five different regencies seated in faraway administrative centres. This lobbying goal was reflected in one of the group's names, 'Team for the Independent Aspiration to Create by Subdivision a Greater Korowai Regency' (Tim Aspirasi Independen Pemekaran Kabupaten Korowai Raya). ${ }^{16}$ The most important current leader of the network plans to write his MA thesis in anthropology on creation of such a regency.

This organisational initiative is an overdetermined reconvergence of this chapter's three subjects of tourism, 'big heads' in a time of redistricting, and migration for school. Adoption of the ethnonym 'Korowai' by this network of students was motivated by Korowai primitivist fame: Korowai people's neighbours have sometimes looked on with dismay at being cut out from international tourism, much as Korowai look on with dismay at being cut out from civil servant jobs. Additionally, the youths' initiative has unfolded in the context of their shared positions in the system of educational migration. The actual political project the youths have come to articulate reflects their situation of tenuous mobility toward civil servant and government posts. Creation of a governmental administrative unit defined by the geography and political interests of their ethno-cultural

\footnotetext{
16 I have also heard the name 'Eastern Korowai Youth Group' (Pemuda Korowai Timur). Some participants also use the terminology of Lembaga Masyarakat Adat, or ethno-cultural NGO, an organisational form that came to wide prominence in Indonesia after 1998. See for example tabloidjubi.com/2013/02/07/wargakorowai-minta-pemekaran/, tabloidjubi.com/2013/02/07/sebagian-wilayah-korowai-masuk-lima-kabupaten/, and 'Masyarakat Korowai Belum Deberdayakan' at www.cenderawasihpos.com/index.php?mib=berita. detail\&id=549 (all accessed March 30, 2013). I have not met the main leaders of this network, but have spoken with certain of them by phone, and some of my Korowai acquaintances have also been on the network's periphery.
} 
confederation is seen as a route to securing those positions, as well as improving the lives of their relatives generally. The youths are seeking a transactional unification of the polarity of primitive 'Korowai' and civilised, prosperous 'big head' or 'Regent', on a different level than the transactional unification brought about by naked performance of martial dances before a visiting official at a village, and yet bearing analogies to such an encounter.

Given the youths' positions as impoverished and politically unconnected students, their advocacy activities may not bear very direct fruit. Yet their example vividly exemplifies broader current patterns of popular consciousness in a regional world deeply organised by logics of the primitive and the civilised, logics that have been molded in new directions in the course of becoming the currency of formal political administration, Indonesian-Papuan domination, market expansion and Papuan interethnic sociability.

\section{References}

Albert, Bruce, and Alcida Ramos (eds) 2000. Pacificando o Branco: Cosmologias do Contato no Norte-Amazônico. São Paolo: Editora USP.

Allerton, Catherine 2003. 'Authentic Housing, Authentic Culture? Transforming a Village into a "Tourist Site" in Manggarai, Eastern Indonesia'. Indonesia and the Malay World 31: 119-128.

Anderson, Bobby 2012. 'Living Without a State: People in Rural Papua are More Interested in Basic Services than Grand Political Struggles'. Inside Indonesia 110: Oct-Dec 2012.

Anderson, Bobby 2013a. 'Land of Ghosts: Papua's Rural Lowlands are Being Transformed by an Encroaching Global Economy, but What Happens to the People There is an Open Question'. Inside Indonesia 112: Apr-Jun 2013.

Anderson, Bobby 2013b. 'The Middle of Nowhere: Highland Communities in Papua are Demanding Access to Services, But There is a Limit to What can be Offered in the Most Remote Settlements'. Inside Indonesia 111: Jan-Mar 2013.

Anggraeni, Dewi 2011. 'Another East: Representation of Papua in Popular Media'. PROSIDING ICSSIS 2011 4th International Conference on Indonesian Studies, FIPB - Universitas Indonesia: http://icssis.wordpress.com/prosiding/ prosiding-icssis-2011/.

Aspinall, Edward 2013. 'A Nation in Fragments: Patronage and Neoliberalism in Contemporary Indonesia'. Critical Asian Studies 45(1): 27-54. 
Backshall, Stephen, Leffman, David, Reader, Lesley and Stedman, Henry 1999. Indonesia: The Rough Guide. London: Rough Guides, 1st Edition.

Bashkow, Ira 2006. The Meaning of Whitemen: Race and Modernity in the Orokaiva Cultural World. Chicago: University of Chicago Press.

BBC/Discovery Channel 2005. 'Tribe'. Bruce Parry, presenter. Season 1, Episode 3: Kombai. Broadcast in US by Discovery Channel under title 'Going Tribal', episode 3 titled 'Living with Cannibals'. Seasons 1-3 published on DVD 2008, season 1 episode 3 titled 'The Kombai, hunter gatherers of the West Papua jungle'. London: BBC Worldwide.

Berkmoes, Ryan Ver, Brash, Celeste Cohen, Muhammad, Elliott, Mark, Holden, Trent, Mitra, Guyan, Noble, John, Skolnick, Adam, Stewart, Iain and Waters, Steve 2010. Indonesia. Melbourne: Lonely Planet, 9th Edition.

Booth, Anne 2011. 'Splitting, Splitting and Splitting Again: A Brief History of the Development of Regional Government in Indonesia Since Independence'. Bijdragen tot de Taal-, Land-en Volkenkunde 167(1): 31-59.

Cahill, Tim 1992. 'No Cannibal Jokes, Please: Upriver into the Swamps of Irian Jaya, and Back in Time'. Outside 17(10): 70-77, 186-196.

Causey, Andrew 2003. Hard Bargaining in Sumatra: Western Travelers and Toba Bataks in the Marketplace of Souvenirs. Honolulu: University of Hawaii Press.

Célérier, Philippe Pataud 2010. “Indonesian Democracy Stops in Papua": Autonomy Isn't Independence'. Le Monde Diplomatique, English edition, June http://mondediplo.com/2010/06/14indonesia.

Cicada Productions/Travel Channel 2007. 'Living with the Kombai Tribe: The Adventures of Mark and Olly'. 6 episodes. Chatsworth (CA): Image Entertainment.

Clastres, Pierre 1977. Society Against the State. New York: Urizen Books.

Dalton, Bill 1991. Indonesia Handbook. Chico (CA): Moon Publications 5th Edition.

Douglas, Bronwen 1999. 'Science and the Art of Representing "Savages": Reading "Race" in Text and Image in South Seas Voyage Literature'. History and Anthropology 11(2-3):157-201.

Douglas, Bronwen 2011. 'Geography, Raciology, and the Naming of Oceania: Journal of the Australian Map Circle'. The Globe 69:1-28. 
From 'Stone-Age' to 'Real-Time'

Douglas, Bronwen, and Ballard, Chris (eds) 2008. Foreign Bodies: Oceania and the Science of Race 1750-1940. Canberra: ANU E Press.

Duncan, Christopher 2004. 'From Development to Empowerment: Changing Indonesian Government Policies Toward Indigenous Minorities'. In Duncan, Christopher (ed.), Civilizing the Margins: Southeast Asian Government Policies for the Development of Minorities. Ithaca: Cornell University Press, 86-115.

Duncan, Christopher 2007. 'Mixed Outcomes: The Impact of Regional Autonomy and Decentralization on Indigenous Ethnic Minorities in Indonesia'. Development and Change 38(4): 711-733.

Fanon, Frantz 2008 [1952]. Black Skins, White Masks. London: Pluto Press.

Ferguson, James 2013. 'Declarations of Dependence: Labour, Personhood, and Welfare in Southern Africa'. Journal of the Royal Anthropological Institute 19(2): 223-242.

Gow, Peter 1993. 'Gringos and Wild Indians: Images of History in Western Amazonian Cultures'. L'Homme 33(126): 327-347.

Hallet, Judith 1994. Treehouse People: Cannibal Justice (Also distributed as Lords of the Garden). New York: Arts and Entertainment Television Networks.

Hastings, Peter 1982. 'Double Dutch and Indons'. In May, R.J. and Nelson, Hank (eds), Melanesia: Beyond Diversity. Canberra: Research School of Pacific Studies, The Australian National University, 157-161.

Hoenigman, Darja 2012. ‘A Battle of Languages: Spirit Possession and Changing Linguistic Ideologies in a Sepik Society, Papua New Guinea'. The Australian Journal of Anthropology 23(3): 290-317.

Hoesterey, James B. 2012. 'The Adventures of Mark and Olly: The Pleasures and Horrors of Anthropology on TV'. In Whitehead, Neil and Wesch, Michael (eds), Human No More: Digital Subjectivities, Un-Human Subjects and the End of Anthropology. Boulder: University of Colorado Press, 245-277.

Institute for Policy Analysis of Conflict 2013. 'Carving Up Papua: More Districts, More Trouble'. IPAC Report No. 3.

International Crisis Group 2007. 'Indonesian Papua: A Local Perspective on the Conflict'. Asia Briefing 66. Jakarta/Brussels: International Crisis Group.

International Crisis Group 2012. 'Indonesia: Dynamics of Violence in Papua'. Asia Report 232. Jakarta/Brussels: International Crisis Group. 
Ipenburg, At 2008. 'Christianity in Papua'. In Aritonang, Jan Sihar and Steenbrink, Karel (eds), A History of Christianity in Indonesia. Leiden: Brill, 345-381.

Jakarta Post 1991. 'Korowai Tribe in Irian Jaya not all Female'. Jakarta Post, 1991/03/20, p. 3.

Killick, Evan 2008. 'Creating Community: Land Titling, Education, and Settlement Formation Among the Ashéninka of Peruvian Amazonia'. Journal of Latin American and Caribbean Anthropology 13(1): 22-47.

Knauft, Bruce 2002. Exchanging the Past: A Rainforest World of Before and After. Chicago: University of Chicago Press.

Knauft, Bruce 2007. 'From Self-decoration to Self-fashioning: Orientalism as Backward Progress among the Gebusi of Papua New Guinea'. In Ewart, Elizabeth and O'Hanlon, Michael (eds), Body Arts and Modernity. Wantage, Oxfordshire: Sean Kingston, 88-107.

Leavitt, Stephen 2005. "“We Are Not Straight": Bumbita Arapesh Strategies for Self-Reflection in the Face of Images of Western Superiority'. In Robbins, Joel and Wardlow, Holly (eds), The Making of Global and Local Modernities in Melanesia: Humiliation, Transformation, and the Nature of Cultural Change. Aldershot: Ashgate, 73-84.

Lekitoo, Hanro Yonathan 2012. Potret Manusia Pohon: Komunitas Adat Terpencil Suku Korowai di Daerah Selatan Papua dan Tantangannya Memasuki Peradaban Baru [Portrait of the Tree People: The Isolated Customary Law Community of the Korowai Tribe in the Southern Region of Papua and Its Challenges for Entering a New Civilization]. Jakarta: Penerbit Balai Pustaka.

MacCannell, Dean 1990. 'Cannibal Tours'. Visual Anthropology Review 6(2):1424.

McWilliam, Andrew 2011. 'Marginal Governance in the Time of Pemekaran: Case Studies from Sulawesi and West Papua'. Asian Journal of Social Science 39:150-170.

Muller, Kal 1990. New Guinea: Journey into the Stone Age. Lincolnwood (IL): Passport Books.

Munro, Jenny 2013. 'The Violence of Inflated Possibilities: Education, Transformation, and Diminishment in Wamena, Papua'. Indonesia 95:25-46.

Nelson, Jimmy 2013. Before They Pass Away. Kempen, Germany: teNeues. 
From 'Stone-Age' to 'Real-Time'

Pagawak, Rony 2007. Sejarah Masuk dan Lahirnya Gereja Injili di Indonesia. Wamena: Lembaga P3 GIDI Wilayah BOGO.

Pandian, Anand 2009. Crooked Stalks: Cultivating Virtue in South India. Cambridge: Cambridge University Press.

Pigg, Stacy Leigh 1992. 'Inventing Social Categories Through Place: Social Representations and Development in Nepal'. Comparative Studies in Society and History 34(3): 491-513.

Rakhmani, Inaya 2012. 'A Note on Jayapura'. Review of Indonesian and Malaysian Affairs 46(1): 151-157.

Reid, Anthony 1994. 'Early Southeast Asian Categorizations of Europeans'. In Schwartz, Stuart B. (ed.), Implicit Understandings: Observing, Reporting, and Reflecting on the Encounters between Europeans and Other Peoples in the Early Modern Era. Cambridge: Cambridge University Press, 268-294.

Robbins, Joel 1994. 'Equality as a Value: Ideology in Dumont, Melanesia, and the West'. Social Analysis 36: 21-70.

Robbins, Joel 2006. 'On Giving Ground: Globalization, Religion, and Territorial Detachment in a Papua New Guinea Society'. In Kahler, Miles and Walter, Barbara F. (eds), Territoriality and Conflict in an Era of Globalization. Cambridge: Cambridge University Press, 62-84.

Robbins, Joel 2009. 'Rethinking Gifts and Commodities: Reciprocity, Recognition, and the Morality of Exchange'. In Browne, Katherine E. and Milgram, B. Lynne (eds), Economics and Morality: Anthropological Approaches. Lanham (MD): Altamira, 43-58.

Robbins, Joel and Wardlow, Holly (eds) 2005. The Making of Global and Local Modernities in Melanesia: Humiliation, Transformation, and the Nature of Cultural Change. Burlington (VT): Ashgate.

Rumsey, Alan 2006. 'The Articulation of Indigenous and Exogenous Orders in Highland New Guinea and Beyond'. The Australian Journal Of Anthropology 17(1): 47-69.

Rutherford, Danilyn 2003. Raiding the Land of the Foreigners: The Limits of the Nation on an Indonesian Frontier. Princeton: Princeton University Press.

Rutherford, Danilyn 2013. 'Living, as it Were, in the Stone Age'. Indonesia 95:1-7.

Salgado, Sebastião 2013. Genesis. Cologne: Taschen.

Schoorl, J. W. 1993. Culture and Change among the Muyu. Leiden: KITLV. 
Scott, James C. 2009. The Art of Not Being Governed: An Anarchist History of Upland Southeast Asia. New Haven: Yale University Press.

Smith, Bernard 1985. European Vision and the South Pacific. New Haven: Yale University Press.

Smith, Bernard 1992. Imagining the Pacific: In the Wake of the Cook Voyages. New Haven: Yale University Press.

Stasch, Rupert 2001. 'Giving Up Homicide: Korowai Experience of Witches and Police (West Papua)'. Oceania 72(1): 33-55.

Stasch, Rupert 2003. 'The Semiotics of World-making in Korowai Feast Longhouses'. Language and Communication 23(3/4): 359-383.

Stasch, Rupert 2007. 'Demon Language: The Otherness of Indonesian in a Papuan Community'. In Makihara, Miki and Schieffelin, Bambi (eds), Consequences of Contact: Language Ideologies and Sociocultural Transformations in Pacific Societies. Oxford: Oxford University Press, 96-124.

Stasch, Rupert 2011a. 'Korowai Treehouses and the Everyday Representation of Time, Belonging, and Death'. The Asia Pacific Journal of Anthropology 12(4): 327-347.

Stasch, Rupert 2011b. 'Textual Iconicity and the Primitivist Cosmos: Chronotopes of Desire in Travel Writing about Korowai of West Papua' . Journal of Linguistic Anthropology 21(1): 1-21.

Stasch, Rupert 2013. 'The Poetics of Village Space When Villages are New: Settlement Form as History-Making in West Papua'. American Ethnologist 40(3): 555-570.

Stasch, Rupert 2014a. 'Primitivist Tourism and Romantic Individualism: On the Values in Exotic Stereotypy about Cultural Others'. Anthropological Theory 14(3): 191-214.

Stasch, Rupert 2014b. 'Toward Symmetric Treatment of Imaginaries: Nudity and Payment in Tourism to Papua's "Treehouse People"”. In Salazar, Noel B. and Graburn, Nelson (eds), Tourism Imaginaries: Anthropological Approaches. Oxford: Berghahn, 31-56.

Stasch, Rupert 2014c. 'Powers of Incomprehension: Linguistic Otherness, Translators, and Political Structure in New Guinea Tourism Encounters.' Hau: Journal of Ethnographic Theory 4(2):73-94.

Steinmetz, George 1996. 'Irian Jaya's People of the Trees'. National Geographic $189(2): 34-43$. 
From 'Stone-Age' to 'Real-Time'

Sudarman, Dea, Blanchard, Claude and Ushiyama, Junichi 1986. Dans les Villages des Arbres. Paris: Adavision. 24m.

Sykes, Karen n.d. The Worth of an Education in Papua New Guinea: Making the Generation Gap. Department of Anthropology, Manchester University, unpublished.

Timmer, Jaap 2007. 'Erring Decentralization and Elite Politics in Papua'. In Nordholdt, Henk Schulte and van Klinken, Gerry (eds), Renegotiating Boundaries: Local Politics in Post-Suharto Indonesia. Leiden: KITLV, 459-482.

Trilling, Lionel 1972. Sincerity and Authenticity. Cambridge (MA): Harvard University Press.

Wamafma, Alex 2008. 'Bertemu Orang Pohon' [Meeting the Tree People]. In Visser, Leontine and Marey, Amapon Jos (eds), Bakti Pamong Praja Papua di Era Transisi Kekuasaan Belanda ke Indonesia. Jakarta: Kompas, 149-174.

Wardlow, Holly 2006. Wayward Women: Sexuality and Agency in a New Guinea Society. Berkeley: University of California Press.

Wahyudi 2010. Membangun Negeri Perbatasan: Kiat Membangun Kampung di Perbatasan Papua. Jakarta: Wadi Press and Pamong Institute.

Widjojo, Muridan 2014. 'Melanesia in Review: Issues and Events, 2013: Papua'. Contemporary Pacific 26(2): 506-516. 